\title{
Social Seducement: Empowering Social Economy Entrepreneurship. The Training Approach
}

\author{
Natalia Padilla-Zea, Stefania Aceto, Daniel Burgos * \\ Universidad Internacional de La Rioja (UNIR) - Research Institute for Innovation \& Technology in \\ Education (UNIR iTED), Logroño, La Rioja (Spain)
}

Received 22 January 2019 | Accepted 1 July 2019 | Published 30 October 2019

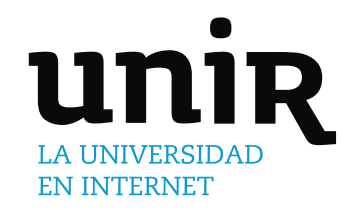

\section{KEYWORDS}

Long-term unemployment is a persistent problem in Europe, following the economic crisis suffered in 2008. This situation reveals self-employment as a good option for becoming re-involved in the working life. In this context, this paper presents a gamified educational platform to empower social economy entrepreneurship skills in long-term unemployed people. In particular, we present the training approach underpinning the motivational process supported by gamification, which has been developed using the ADDIE model. The learning path is developed according to a story that guides the work throughout the training process. It is based on the premises of alignment with reality, instruction from didactic material and real-life stories, in-game practice, work in groups and assistance from a facilitator. This approach covers the competence needs identified in a previous study and includes gamification techniques to improve motivation and engagement. Therefore, the training program comprises: (1) a set of materials and real social economy enterprise experiences, which are the basis for learning and getting inspiration; (2) activities to develop a business plan based on concepts learned from the learning materials and from real-life stories, as well as the help of a facilitator who walks with trainees during the process; (3) a set of individual and group, mandatory and optional assessment activities to evaluate the learning achieved; and (4) a three-views scoring system that shows learning progress for individuals and groups, and gives players the opportunity to exchange gamification points for benefits in the game. The results presented in this paper are based on a sample of two pilots run in Italy and Spain and involving five facilitators working with around 60 learners. About $60 \%$ of participants indicated their intention to apply knowledge obtained in a real-life entrepreneurship initiative.
Gamification,

Pedagogical Model, Social Economy, Social Seducement, Teamwork.

\section{INTRODUCTION}

A NTHROPOLOGY combines sociology, psychology, biology, and the humanities to carry out deep analysis of human beings and social groups [1]-[4]. Entrepreneurship uses the same combination of sciences to implement specific actions towards a clear and tangible objective [5]. Games are a key part of this analysis in any type of society or cultural representation [6]. Through play, children develop key abilities, from hunting to counting, through solving problems and by learning other fundamental skills that will support them when they become adults. For adults, games are the natural way to approach situations, such as negotiations and meetings, in which everyone plays a role and must find his or her place and a way of communication [7], [8]. Entrepreneurs can use the key features of games to achieve objectives and acquire specific competences [9], [10]. Nowadays, the social unit consists of distributed contacts and cloud services, which facilitate a 24/7 umbilical connection of the individual to the group [11], [12]. With this background, eGames and gamification techniques look like a natural evolution in achieving real entrepreneurship competences in a

* Corresponding author.

E-mail addresses: natalia.padilla@unir.net (N. Padilla-Zea), stefania.aceto@unir.net (S. Aceto), daniel.burgos@unir.net (D. Burgos). digital context, one that is based on interaction and social strategies with social networks, learning management systems, entertainment apps and digital tools that support and extend social contacts. In this setting, learning happens anytime, anywhere. This is the approach of digital anthropology [13], in which groups are analysed as a combination of cultures and contexts.

Furthermore, while working with traditional group skills and interaction, there are a number of features on which researchers focus their attention [14]-[16]: for example, social identity, the user's role in a group, social forms of expression, the group's need for assembly and the development of personal and group skills for improving social reputation. We find similar features in digital entrepreneurship, but in a particular representational medium [17], [18]. Enabled by social networks and Internet apps, individuals and groups can share and express themselves (e.g. via Facebook and Instagram); meet for discussion (e.g. through Google Hangouts and Skype); provide opinions, argue, and call for justice (e.g. on Twitter and WhatsApp); create music (e.g. with Garage Band); and work (e.g. using Outlook, Calendar, and OpenOffice). Social roles within the group are also required for interaction (e.g. adopting the role of a follower or an alpha male). In short, there are many similarities between these and other social structures that are usually the subjects of anthropological studies.

In this context, games play a role in helping individuals achieve social status, develop social skills and personal competences, and adopt roles in group interaction [19], [20]. The positive and negative sides of 
games have been discussed by Prensky, Gee, and others [5], [21].

For example, the dark side of games might be used for promoting effective learning and interaction, including the ability to overlap tasks, leading to skills in multitasking; the manipulation of social identification through color, dress codes, and strange jargon; encouraging social skills for empathy and creating internal relations inside a group; and, finally, for cultural integration. Furthermore, functional diversity based on the inclusion of over-gifted individuals, who are barely integrated into the group but possess special features that make them unique, becomes a one-in-a-million feature that makes a group stand out. All those examples present numerous 'bad habits' related to games, which can be turned upside down in order to support effective and useful learning and interaction. The main objective of our research is to use the best features of games to support entrepreneurs' achievement of specific competences through social interaction and gamification. We discover how to match the social behaviour of individuals and groups through an educational digital game design to spur the process of learning personal skills [22], [23]. Furthermore, we examine those skills derived specifically from recurrent patterns, which can be used for learning and the development of personal and social competences [24], [25]. In doing so, we provide a new approach to the use of eGames, not just as a tool for learning, but as a vehicle for social entrepreneurship and personal behavior analysis, moving towards personalised support offered to every user and group, which is based on individual inputs and pattern identification.

The rest of the paper is organized as follows: in section II, we present a set of related works, including some of the social-entrepreneurship game-based proposals that we have studied; section III gives a general overview of the Social Seducement project, stating its main features; section IV outlines the Social PlaNet gamified learning platform developed as part of the Social Seducement project; section V presents the pedagogical model designed for this eGame; section VI describes the assessment performed on the pedagogical model; and section VII summarises our main conclusions and further works.

\section{RELATED WORKS}

The work presented in this paper has been developed as part of the Erasmus + Social Seducement project. The research consortium studied different proposals included in the Guide for Developing the Game and its Environment [26] and analysed several internal and external experiences, which have also been summarised in this paper.

Games and gamification took a key role in education innovation some years ago, as we can see, for example, in the NMC Horizon reports from 2013 to 2017 [27]-[29], which state the potential of these approaches to improve students' motivation and engagement. Moreover, there has been an evolution of games used in education, which have been paired with learning pedagogies [30]: a first approach based on behaviorism, where a reward was given for every correct actuation; the next one, based on cognitivism and constructivism, where students learned from past experience and from experience in the virtual environment in collaboration with other partners; and the third one, based on constructionism, where simulations are offered to ease the transfer of knowledge.

Many studies have been carried out in this field, obtaining positive results in several areas that support the theory of game-based learning. A review of the most relevant ones is presented in McClarty et al. [31], which seeks to clarify their strengths and weaknesses. In particular, this review concludes that games have the potential to successfully improve the pedagogical approach's playfulness, personalize learning, improve engagement with the process of learning, teach twenty-first-century skills, and provide sound assessment of learning. The authors highlight the specific features that have allowed games to become a new tool for learning: immediate feedback, failing without consequences in the real world, a low level of frustration compared to that in traditional education, learning from mistakes, improvement of motivation and progressive growth of difficulty across levels. Particularly relevant in this context is games' ability to train learners in problem-solving, innovation, and decision-making, important skills in the current society.

However, there has been one lingering concern about the suitability of using games, posed by Uliscak [32]: '[O]ne of the major concerns identified about using digital games in education is the difficulty in assessing effectiveness at achieving the learning goals. How does a player of Civilization, for example, demonstrate that they know the seven wonders of the ancient world rather than merely acquiring stars?' As Jeffery Chin and colleagues state [33]: 'Designing ways to collect data on student learning in simulation and gaming is particularly difficult because of the open-ended nature of these activities.' This issue can be more easily addressed by teachers, who can act as facilitators or mediators of the process of learning. The teacher can lead, stimulate, and make explicit what the student learns.

Malone [34], cited in [35], defines some key elements of the design of an educational game:

- The activity should be structured in such a way that players can increase or decrease the difficulty of challenges faced, in order to match exactly personal skills with the requirements for action;

- It should be easy to isolate the activity, at least at the perceptual level, from other stimuli, external or internal, which might interfere with involvement in it;

- There should be clear criteria for performance; a player should be able to evaluate how well or how poorly (s)he is doing at any time;

- The activity should provide concrete feedback to the player, so that (s)he can tell how well (s)he is meeting the criteria of performance;

- The activity ought to have a broad range of challenges, and possibly several qualitatively different ranges of challenge, so that the player may obtain increasingly complex information about different aspects of her/himself.

An additional element to be considered is that, in our case, the target group is made up of long-term unemployed people, the majority of whom are at risk of social exclusion. The number of proposals about the corporate sector is significantly higher than the number of proposals in formal education, although there is still a lack of evidence about the effectiveness of eGames in social inclusion. This subject has been studied by Stewart et al. [36], who conclude that digital game-based approaches provide adaptable, motivating, and engaging techniques that can be used to empower individuals and enhance social inclusion. More concretely, they state that 'the use of digital games and gaming is starting to show potential in addressing issues of policy concern including wellness and ageing, education and employability of poor learners, improved quality of training, skills development and civic participation'. Moreover, in this study, the role of 'intermediaries and professionals working in the field of social inclusion' is stated as a key enabler of inclusion. We could assume the same role for teachers, trainers, and learning facilitators as mediators in the learning process via educational games.

Following the review of the trends and challenges of using online games for learning, a process of research on relevant practices was developed [26], whose relevance in the scientific community is currently growing [38]. In Table I, we have included several games used in the context of learning and training for vocational jobs, social entrepreneurship skills, and any other feature to improve learners' capabilities to run social enterprises.

From this review, and after a process of analysis on several criteria (game objectives, tools used to achieve the project goals, target groups, methodologies applied or underpinning the learning 
model, assessment and artwork), a reduced set of key practices was selected, as shown in Table II. These helped the consortium to get inspiration and to decide some of the features of the gamified training solution to be developed.

Thus, from the analysis of the games and projects presented in this section and according to the goals and target group of Social Seducement, we conclude that the pedagogical approach needs to be linked to the social reality of participants to provide them with a situated and experiental learning experience without losing motivation. In addition, a clear mechanism to assess progress is needed, and immediate feedback needs to be provided. Moreover, supporting disadvantaged learners is a key point in Social Seducement, as doing so promotes civic participation and social skills. For that reason, it was judged necessary to include the role of the facilitator (a sort of game master who will facilitate the learning of game users throughout the

TABLE I Sample of Games to Learn or Train Social Entrepreneurial Skills (Adapted from [26])

\begin{tabular}{|c|c|}
\hline Reference & Games and projects scanned \\
\hline [39] & 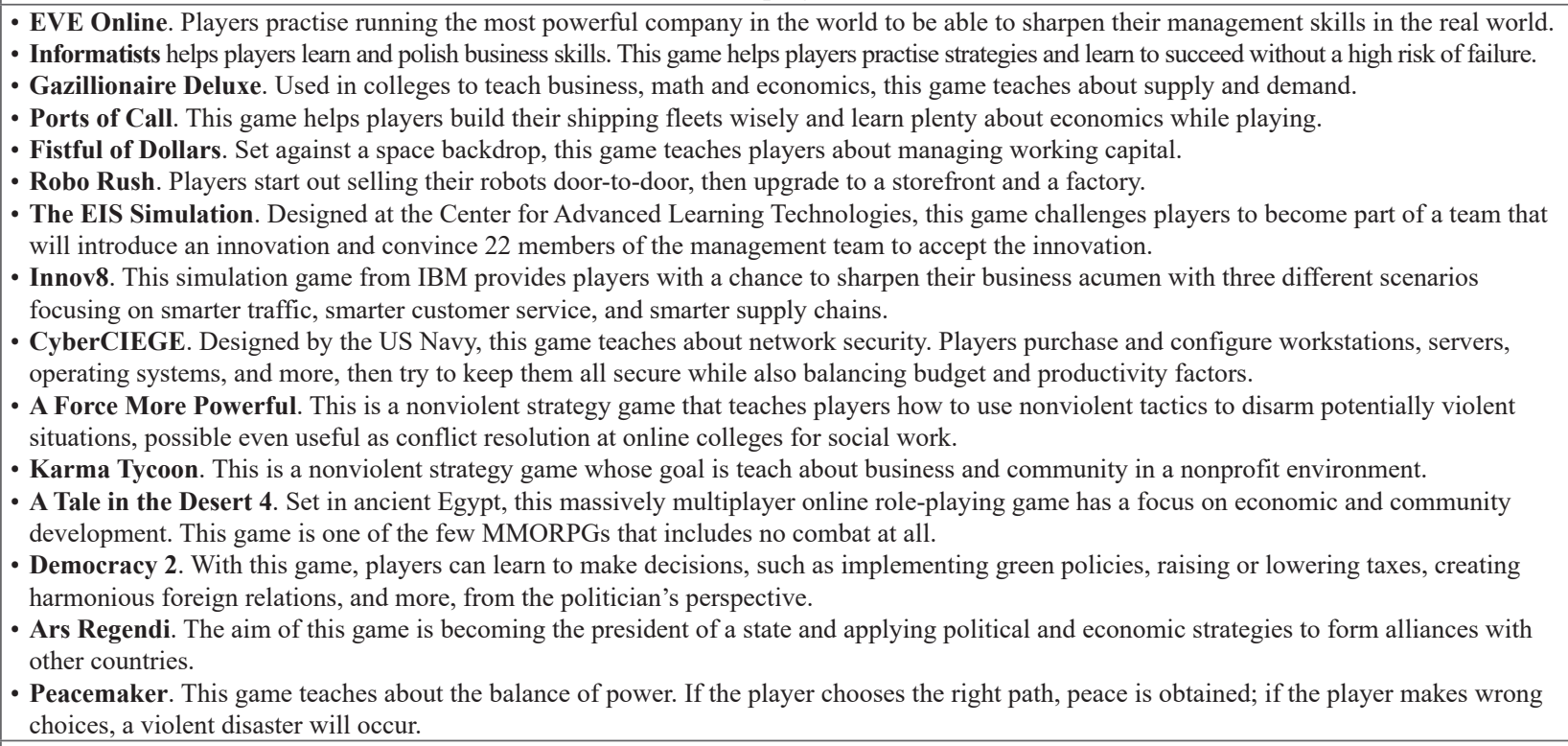 \\
\hline [40] & $\begin{array}{l}\text { - The New Heroes tells the dramatic stories of } 14 \text { daring people from all corners of the globe who, against all odds, successfully alleviate poverty and } \\
\text { illness, combat unemployment and violence, and bring education, light, opportunity, and freedom to poor and marginalised people around the world. }\end{array}$ \\
\hline [32] & $\begin{array}{l}\text { - SimVenture is a business simulation game designed for people } 14-30 \text { years old who are learning about the realities of setting up a business. } \\
\text { - Climate challenge game is an online sandbox-style strategy game developed by Red Redemption Ltd. Its aim is engaging } 20 \text { - to } 35 \text {-year-old } \\
\text { professionals in the realities of climate change and measures that can be taken to decrease carbon dioxide emissions. }\end{array}$ \\
\hline [41] & - White Card Game. This game is intended to promote safety practices in carpentry workshops. \\
\hline$[36]$ & $\begin{array}{l}\text { - In-living. To help young people become good tenants. } \\
\text { - Rock'n'high roller. For financial planning, addressing people aged } 18 \text { to } 24 \text {. } \\
\text { - Footfall. To help young people learn financial responsibility for small businesses. } \\
\text { - TARDIS project. To improve interview skills of young people with low employability. } \\
\text { - No credit, Game over. To train young people in debt management. } \\
\text { - Thuis in the Netherlands. Supporting migrants in the preparation of the naturalisation exam. } \\
\text { - Mixopolis. Vocational orientation and participation for young migrants. }\end{array}$ \\
\hline [42] & 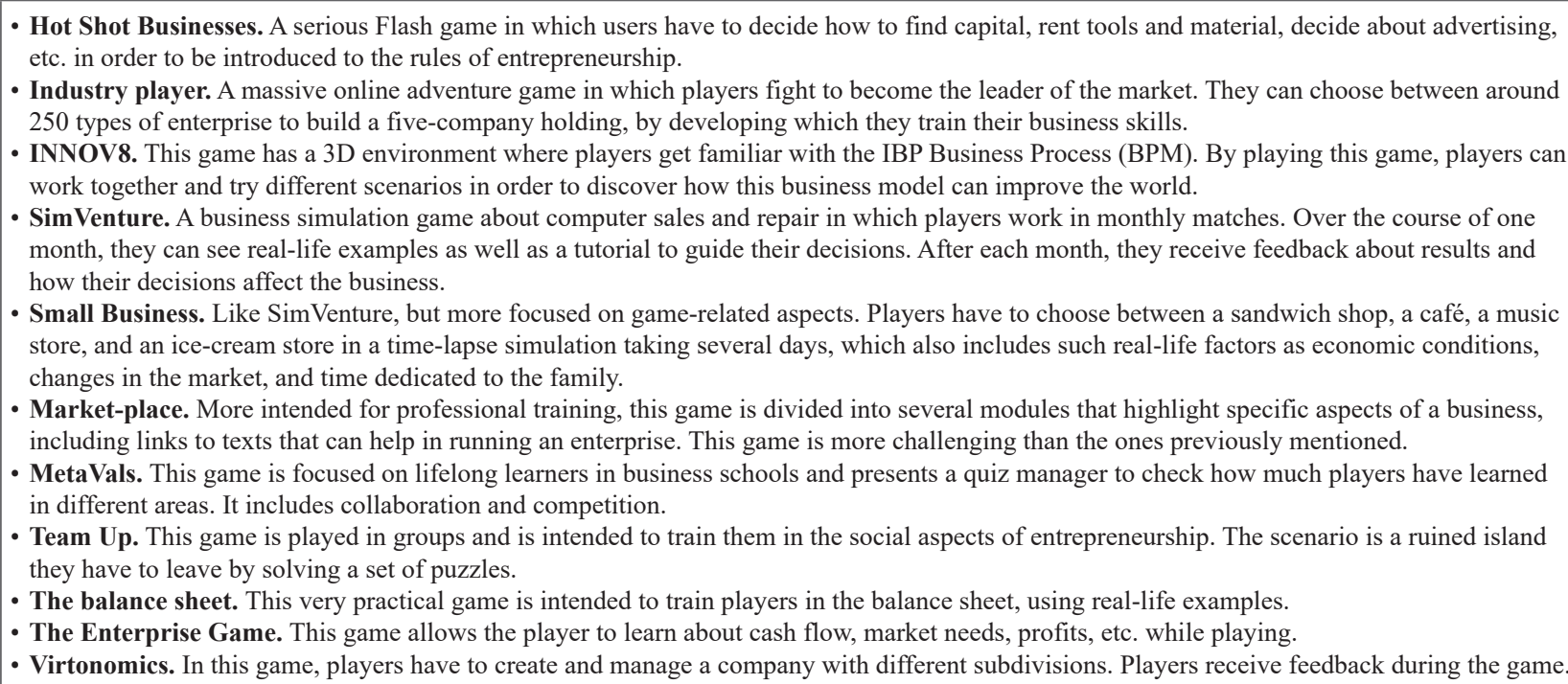 \\
\hline
\end{tabular}




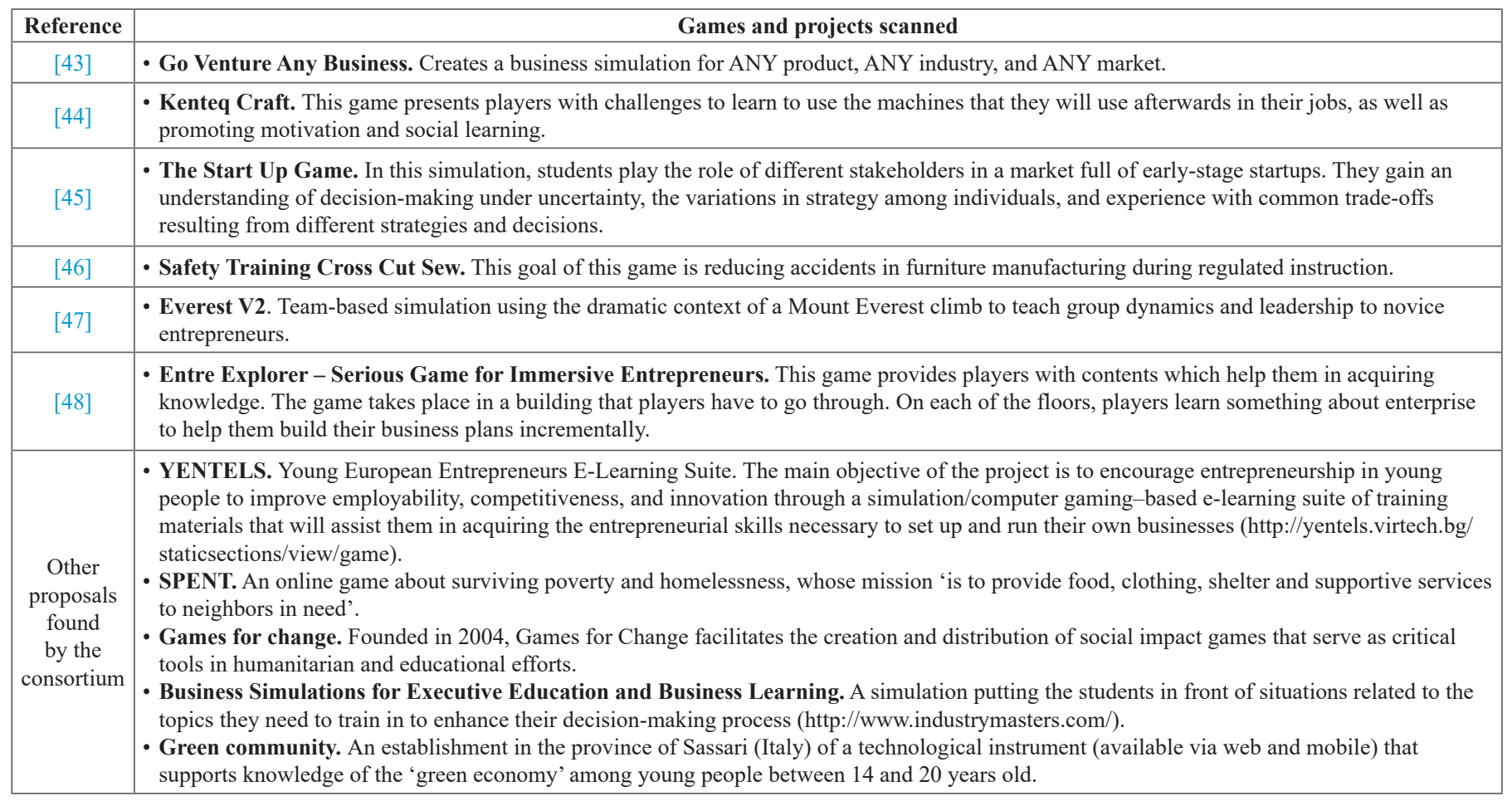

TABLE II. Selected Practices for Social Seducement (Extracted from [26])

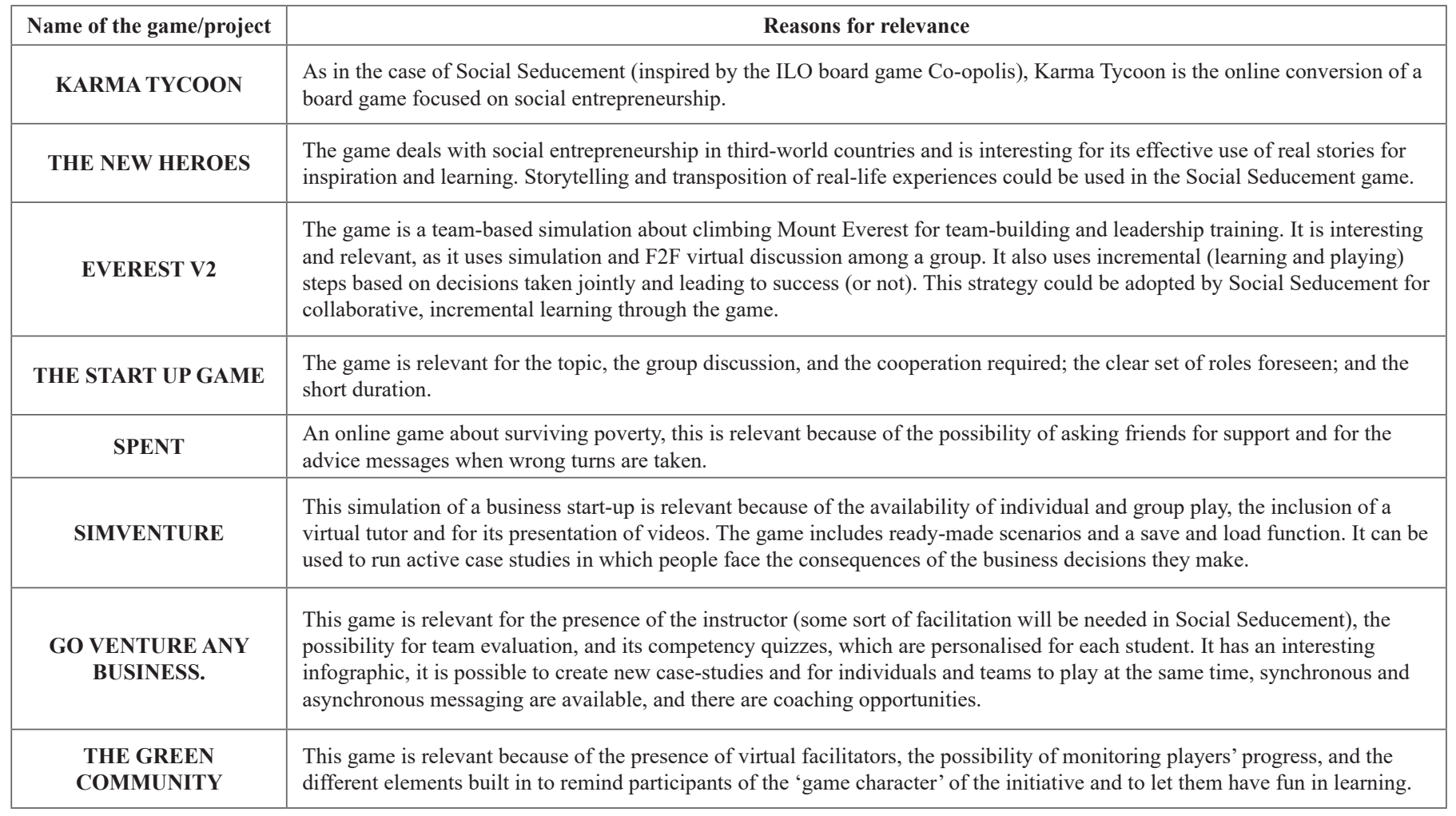

game, supporting teamwork, animating the groups of learners, and supporting project partners in the assessment of the game experience) in order for learners to be accompanied in their learning journey through the gameplay, and therefore in the acquisition of skills.

\section{Social Seducement Project: An Overview}

The Social Seducement project aimed to foster self-empowerment and entrepreneurship attitudes within disadvantaged groups in Europe, with a focus on unemployed adults aged $18+$. It did so by engaging such groups in a gamified training solution, of type Online Role-Playing Game (ORPG), that introduced them to a world of social collective cooperatives and guided them through the principles, concepts, and practices necessary to be able to set up and successfully manage a social enterprise, with specific reference to social cooperatives.

The project was developed thanks to the support of the European 
Commission, in the frame of the Erasmus Plus Program (Strategic Partnerships in Adult Education). It gathered a group of partners located across the UK (Tavistock Institute of Human Relations, coordinator), Spain (Universidad Internacional de la Rioja), Italy (Ecobyte and Le Mat), Belgium (REVES - European Network of Cities and Regions in the social economy), and Sweden (Coompanion). The partners all had different backgrounds and expertise, which was a strategic design choice made to guarantee the availability of all the necessary competences an innovative project like this one needs to be successful. In particular, it leaned on the experience of the coordinator in the field of social sciences, which was necessary to design the methodological approach taken in the project; on the technical experience of UNIR in the field of game architecture design; and on the experience and networking capacity of social partners (Le Mat, Coompanion, and REVES) in adapting the game to the needs of the target group.

The project included the following main phases:

- Target needs analysis and game design: Based on desk and field research, the project mapped similar experiences in the field (i.e. online games about social economy), identified the needs of the target group (unemployed) in terms of training to become social entrepreneurs and elaborated a possible architecture for the game.

- Game development: Based on the outcomes of the previous phase, the project team developed the online game and gathered the necessary training material to support learners in their learning process while playing the game.

- Facilitator training: The facilitator was introduced as a sort of game master facilitating the learning of users throughout the game, supporting teamwork, animating the groups of learners and supporting project partners in the assessment of the game experience.

- Piloting: Five pilot countries were involved (UK, Italy, Spain, Sweden, and Belgium). In each country, the game was tested with 36 learners (divided into small groups), who played the game with the support of a facilitator. There were three facilitators per country, with each facilitator supporting at least two groups of learners.

- Validation: Based on the pilot results, the game was finalized and made available to the public (with special reference to employment and training centres, and all those entities supporting employment, employability, and social inclusion).

Social Seducement was an innovative project in that it developed an ORPG in the social economy field. The mapping carried out in the first phase of the project revealed a substantial lack of similar experiences in the field. Addressing disadvantaged groups (the unemployed, who are in a fragile situation in terms of self-esteem and self-confidence most of the time) and training them in the creation and management of social collective cooperatives (involving teamwork, respect for others, collective decisions, and collective responsibilities) poses a lot of challenges in the design of an online game, which has its own technical rules and requirements.

\section{Social Seducement Project: The Gamified Learning EXPERIENCE}

As result of the work in the Social Seducement project, the gamified learning platform Social PlaNet (http://ss.epscms.com) was developed. In this learning experience, groups of students learn about the Business Model Canvas (BMC) to be applied to a social economy enterprise idea, which will be developed while they are working on the platform.

The story underpinning the learning experience is about a group of neighbours who meet in a cafe in a European city and are recruited by a magical person to run a social economy enterprise (Fig. 1) [50].

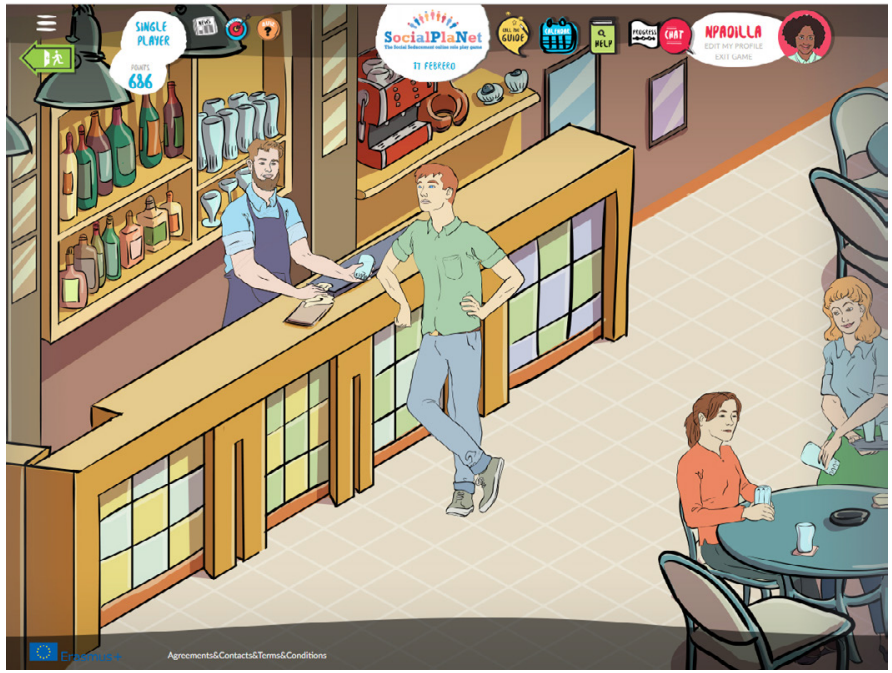

Fig. 1. Cafe in the Social PlaNet platform.

The group of potential entrepreneurs has to start the process of developing the idea for their enterprise. The first step is looking for an office where they can work and going to the library to get some information about social entrepreneurship. The BMC arises as an ideal tool to find and study the different elements involved in the development of the enterprise idea, and learners need to think about each of them: key partners, key activities, key resources, value proposition, customer relationships, channels, customer segments, cost structure and revenue streams. These elements are structured in three chunks, as shown in Fig. 2, which will be accessible from the office as well as from the library (Fig. 3).

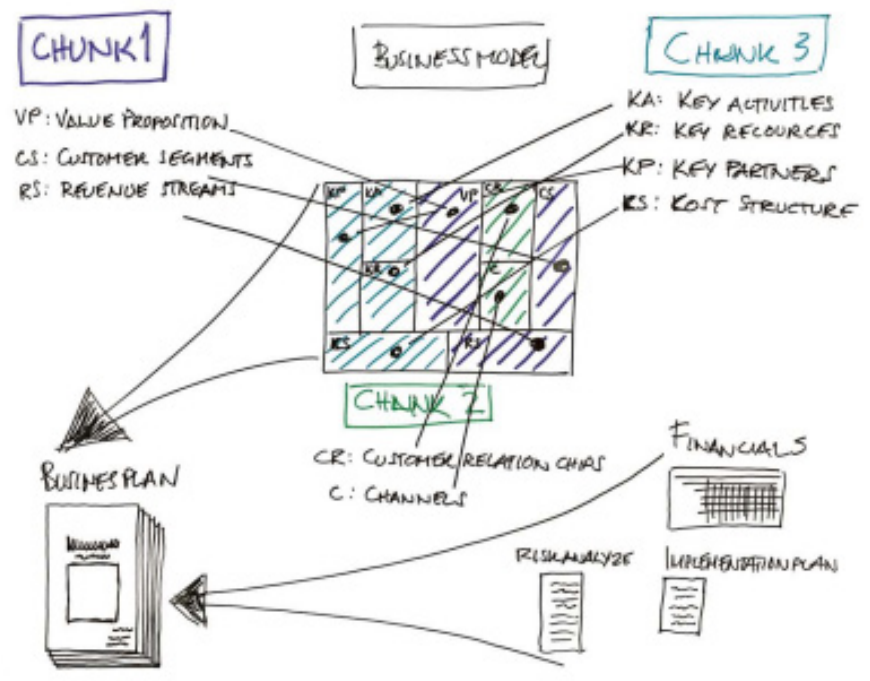

Fig. 2. BMC chunks assignments in Social PlaNet [extracted from 50]. 


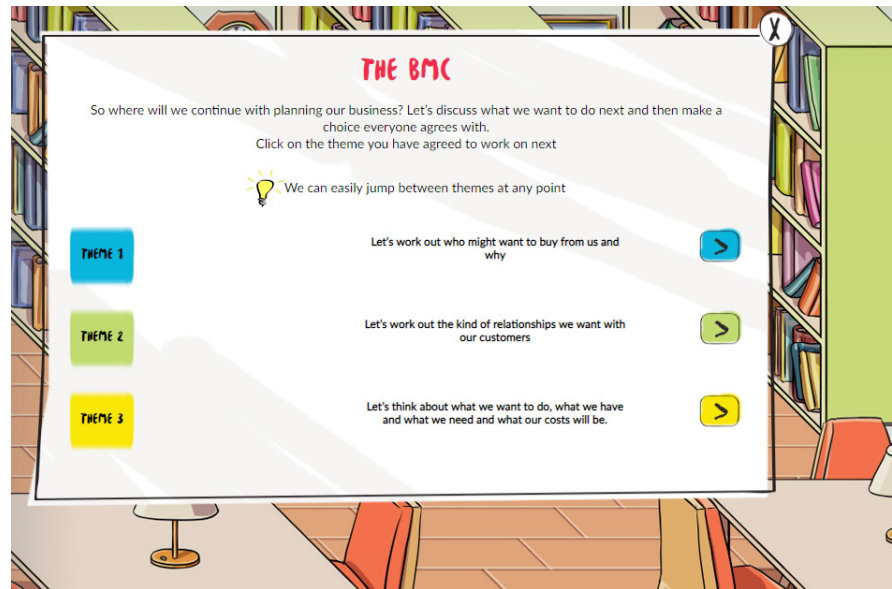

Fig. 3. BMC access.

The learning experience implemented in Social PlaNet has been divided into eight levels (Table IV), from user registration to building an optional business plan. The gamified strategy encourages learners to progress. The main idea of this gamification approach is to reward group activities more than individual ones and use points obtained to allow learners to furnish their office. That way, each piece of furniture has a cost in points, and the group can 'buy' each of them when they obtain the necessary number of points.

During this learning process, students have to develop the BMC in groups. To set up the group session, they have to arrange a meeting and connect to the platform at the date and hour previously agreed in the platform schedule. However, a single user can connect to the platform in an individual session for a deeper study or a wider read of the materials. A learner can start an individual session whenever a group session is not fixed (see Fig. 1, upper left corner: 'single player'), but (s)he will be not allowed to further develop the BMC.

A role-based approach is included in order to develop students' soft skills. A group member is randomly selected to be the task leader in each of the group sessions. The task leader is responsible for organizing the group discussion, extracting the main ideas and promote agreement between group members in order to register the agreement in each phase of the process. This role can be rejected and the former learner can select another partner to play that role. Only the task leader is allowed to fill in the blanks with the information agreed to by the group. For example, in Fig. 4, the group has agreed how to transport its products.

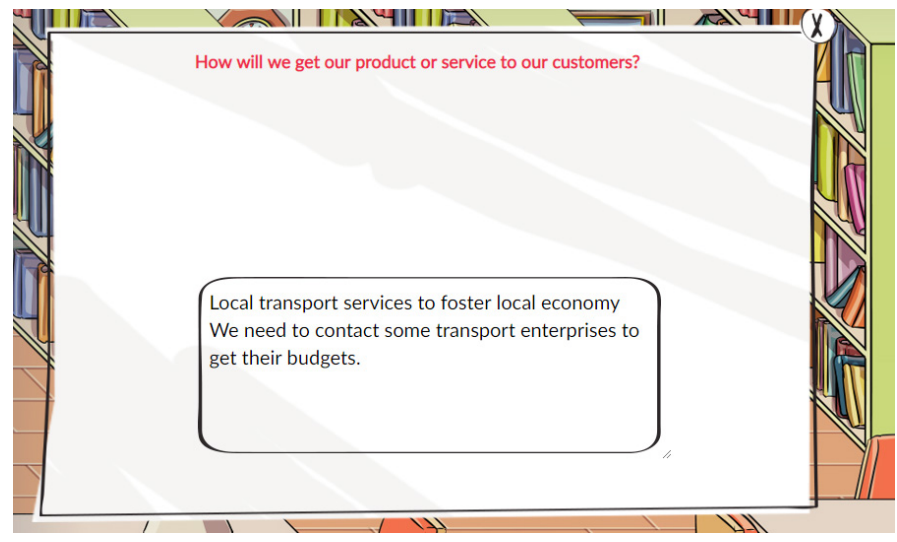

Fig. 4. Group agreement about product transportation.

During this training course, a facilitator helps the group to advance in its BMC development. This facilitator reviews progress and is available to solve any doubts arising in the group. To contact him or her, both individual and group sessions have an icon participants can click to chat with the facilitator (CALL THE GUIDE), in addition to the one they have for internal discussions (CHAT) (Fig. 5).

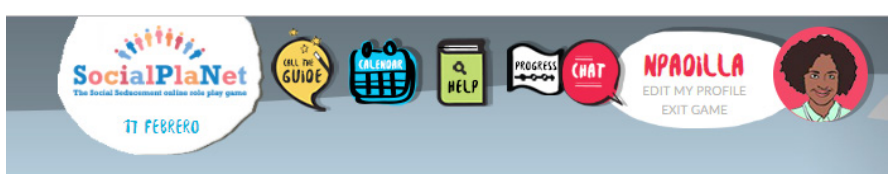

Fig. 5. Icons in Social PlaNet: call the guide, calendar, help, progress and chat.

Moreover, a selection of real social economy enterprise stories is available on the platform to foster brainstorming in each of the levels. As the group goes forward, the stories are unlocked and students can read about the specific item on which they are working. These stories are based on real cases the project partners collected by contacting national social economy enterprises.

To succeed in this learning experience, the group has to finish the $\mathrm{BMC}$ for the idea initially posed. At the of the process, when they have filled in the BMC, they can spend the remaining points in their office or continue developing a final business plan, which will be printed as a pdf file with all the information developed by the group.

\section{Social Seducement Project: The Training Approach}

As previously stated, Social Seducement is a gamified learning platform intended to train long-term unemployed people in social entrepreneurship skills. By participating in the pilot, groups of learners came up with their business ideas using the Business Model Canvas (BMC). In this section, we focus on the pedagogical approach underpinning the learning process.

\section{A. Foundations}

The pedagogical model introduced in Social Seducement has been developed on the basis of three main pillars [51]: (1) the ADDIE instructional design model; (2) the European Qualification Framework, to split the assessment model into knowledge (to know), skills (to be able to) and attitudes (to behave with); and (3) a comprehensive competences framework for social economy entrepreneurs.

ADDIE (Analysis, Design, Development, Implementation, and Evaluation) [52] is a successful and widely used instructional design model comprised of five phases. One of the most important characteristics of this model is its ability to be applied both iteratively and sequentially, which offers the instructional designer some freedom in developing the instruction. Next, we present a brief explanation of each of its phases, including how they have been implemented in our project:

1. Analysis, in which the scenario has to be defined: students and their characteristics, context of use, available resources, etc. In Social Seducement, this phase was performed by delivering a survey to a wide range of key actors in social economy entrepreneurship in order to find out about the needs associated with the creation of a cooperative social enterprise. Additionally, conclusions from this study were compared to a literature review, which allowed for adjustment of the conclusions obtained.

2. Design: Tasks to be performed in this phase are related to learning itself. Thus, the teacher or instructor has to describe the goals, determine how they are going to be assessed, choose the way to provide students with materials, define the general didactic model, plan instruction by deciding the elements and order of the content, design activities for students and identify resources they need. In Social Seducement, this phase has been developed by structuring contents into levels in the game and by managing progress through the storytelling that guides the game. 
3. Development: This phase is intended to generate the educational content designed in the previous phases. In Social Seducement, it was developed by proposing a set of materials, which were divided into external and internal materials. The external material is a set of links to resources (texts, videos, wikis, etc.) on the web, including concepts about social economy enterprises and how to manage every step in their development and operation; the internal material is a set of real-life stories intended to give inspiration to learners while they are playing. Partners of the consortium gathered these stories from enterprises in every country.

4. Implementation, in which the instruction takes place: In this phase, the instructor has to promote students' understanding of the content, support their learning and follow up on their progress. In Social Seducement, this fourth activity was developed in a pilot process in five countries: Italy, Spain, Belgium, Sweden and the United Kingdom. Additionally, before testing the game, we tested the instructional model itself, in order to avoid pitfalls once that model is included in the platform.

5. Evaluation: Given the possibility of applying this model both iteratively and sequentially, evaluation could be formative or summative. The complete game Social Seducement will be tested and results in this phase will be used to refine and validate it. Results of the pedagogical model test will also be evaluated to improve the final version to be included in the game.

The pedagogical model of Social Seducement is intended to train people in competences identified in the European Qualification Framework, which separates them into knowledge, skills, and attitudes [53]. For that reason, our assessment model is also organized into these three parts, each of them involving specific activities. However, since competences are difficult to assess, it was decided to evaluate learners' achievements based on learning results. A complete list of learning results for each competence was developed [54], without detriment to a learning result that could promote the acquisition of more than one competence at the same time.

Finally, a comprehensive portfolio of competences was developed based on a revision of the relevant literature on social economy enterprises and a survey of local actors in the different of consortium members' countries [54]. This portfolio, which falls outside the scope of this paper, covers a complete set of competences needed for prospective and struggling social economy entrepreneurs, grouped into (1) organization of social economy enterprises; (2) knowledge of the environment of the social economy; and (3) individual competences that smooth the running of a social enterprise.

\section{B. Learning Structure}

Using the competence portfolio, consortium members developed a high-level view of the learning results that social economy entrepreneurs are intended to achieve. However, in order to be able to assess what they are actually learning during the training process, the attention was focused on learning results, which can be analysed at a lower level. A set of competences that social economy entrepreneurs need to run their social enterprises was obtained from the prior knowledge of partners in the consortium, the literature review and the survey findings. That way, the complete and complex portfolio was easier to manage and understand. Below, we present the set of competences packages obtained by partners of Social Seducement from that process [50]:

- Understanding the concept of social economy. Social economy enterprises have several features that differentiate them from traditional enterprises, such as governance type, use of benefits, and rules and regulations related to tax. Therefore, learners need to learn these principles to run the idea properly.

- Conception of the idea by a group of persons. Since the game is played in groups, learners need to develop their skills to work collaboratively to conceive and develop their business idea. In this package, players will train empathy, listening capacity, mediation capabilities, etc.

- Establishing a business plan. To achieve a proper business plan, several competences need to be trained, such as research and analytical capabilities, development of a market study, and using financial instruments. Additionally, editorial skills are needed to write the business plan and present the idea and proposals to stakeholders. The capacity to learn from previous experiences to adapt the business plan to changes in the local environment is also necessary.

- Management, including communication and marketing. In this package, skills related to bookkeeping, the legal environment, administrative requirements, etc. are trained for. Learners will also need to be able to organize meetings, plan, make decisions, use IT instruments, etc.

- Creation of a conductive stakeholder environment. Knowledge of and commitment to the local area is essential for social economy enterprises, as is direct contact with local authorities, other social economy or traditional enterprises, universities, citizens, etc. These relationships allow entrepreneurs to identify local needs, define and develop proper activities to solve these needs, and adapt to local evolution.

- Evaluation and impact assessment. Social economy enterprises also need to evaluate their activities and revise strategies on the basis of the results obtained or to attract new investors according to the impact achieved.

- Operations. Beyond development of the idea or planning strategies to be developed in the local environment, a social economy enterprise needs to be managed daily. For example, deliveries to customers, meetings with local actors, and negotiations with banks need to be maintained and studied in order to properly assess the implications of these actions and how they will (or won't) help the business.

Until now, we have three elements to be combined in the training process: (1) the competences portfolio; (2) learning results; and (3) competences packages. In order to make explicit the relationships among them, we will use the term 'learning outcome' to refer to learning results related to several competences in the competences portfolio. Thus, in Table III, we show how they are related [50].

\section{Learning Materials}

In Social PlaNet, learners are provided with two kinds of material [50]: the first type, external material, is a set of documents, videos, references, etc. where they can find conceptual knowledge about social economy, enterprises, social economy enterprises, etc. The second type, internal material, is a set of stories of real social economy enterprises (see Appendix I for an example) running in the different countries of the consortium, which are intended to give inspiration to learners in the process of developing their ideas to build their own social economy enterprises.

In the first group, contents have been divided according to learning outcomes, and subsections have been formed to encourage learners to focus more precisely on what the reference is about. Throughout the training process, these concepts will be shown to learners when they need to know them to face or be prepared for the activities in every level. Each country has a different set of links available because legislation concerning social economy enterprises varies nationally. External learning material for Spain is included in Appendix II.

On the other hand, we have internal materials. A set of 20 stories are included on the Social PlaNet platform. These have been split in several 
TABLE III. Relationships Between Learning Outcomes and Competences in the Portfolio (Extracted from [50])

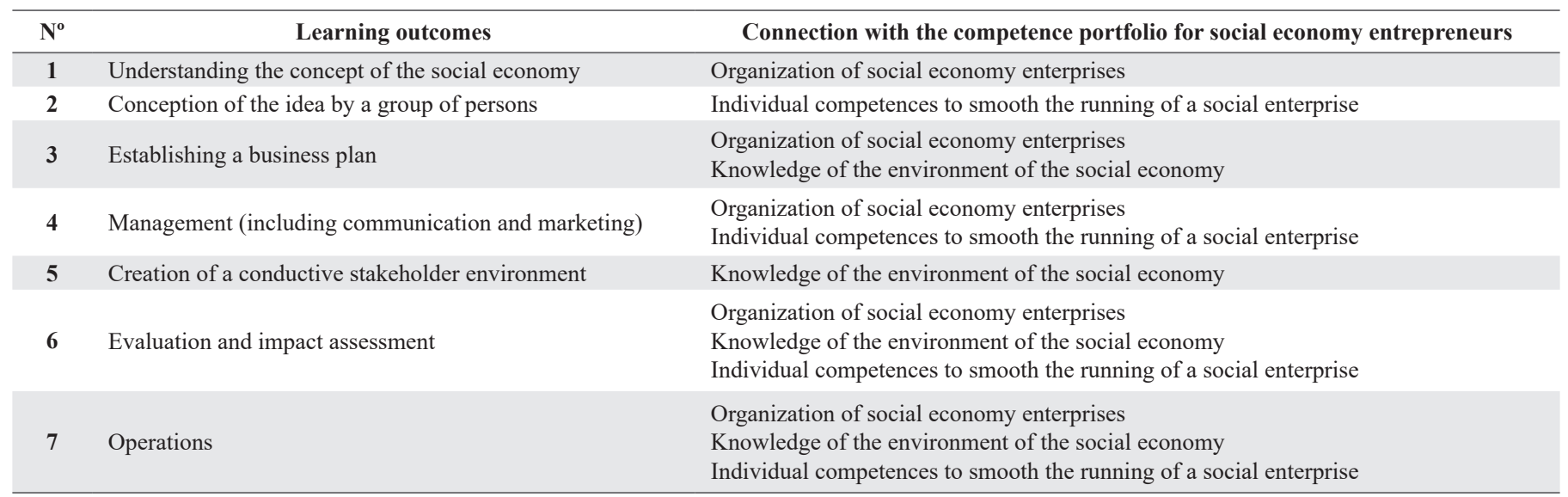

parts according to the contents that learners need in every scene in the game. Thus, each part begins with an introduction of the enterprise, in order to contextualise the story. If learners have already read any other part, they can skip this introduction and focus on the specific part that they need. After that, according to the scene in the platform where learners are, they can read about how to manage concrete situations in the starting up or running of one of these enterprises, some questions for them to think about and the solution that enterprise gave, as well as its implications.

\section{Learning Assessment}

In order to continue advancing in the platform, learners have to pass several quizzes based on the content they have previously covered. If learners obtain a score of more than $60 \%$ on quizzes, they will continue to the next level. If not, they will be encouraged to review some specific internal and external material to learn more about these concepts. Materials that will be presented will be the ones they have not yet read or, if all material has already been read, the ones most closely related to the main concepts in that level.

The first step to properly situate these quizzes is to allocate content and quizzes along the levels (Table IV). To present this distribution, we show where the learning outcomes are trained for in the game and mark the assessment points, including a description of what we assess in each of them [50].

The program-level learning outcome assessment works on the three defined levels of knowledge, skills and attitudes. In particular:

- Knowledge assessment performed throughout the game is structured around several kinds of quizzes, which are to be solved individually or in groups, in order to promote individual commitment, learning by doing and collaborative learning. The correctness of the solutions is checked automatically.

- Skills assessment (optionally performed at the individual level) will occur (1) through self-evaluation of learners at the beginning and at the end of the game (learners will complete a questionnaire at the beginning and at the end of the game to be aware of their selfperception and progress thanks to the game); (2) through automatic tests while the game is played; and (3) through qualitative evaluation by the facilitator.

- Attitude (behaviour) assessment is mainly provided by the facilitator (both at the individual and at the group level), being promoted by a gamified approach intended to improve motivation $[56]$.

\section{Assessment Milestones}

In order to avoid overloading learners, we have identified some moments in the game where assessment plays a key role to verify the acquisition of knowledge, skills, and behaviors. These key moments are:

- Level 3 (Entering headquarters, defining roles), where a first assessment of skills happens.

- Level 5 (Look at your group: do you have basic features to realise the idea?), where, having presented some examples of social economy enterprises, we assess if learners understand what a social economy enterprise is and is not.

- Level 7.1.1 (Value proposition), where we assess the learners' knowledge of the meaning of value proposition in social entrepreneurial thinking.

- Level 7.1.2 (Customer segments), where, once customer segments can be managed, we assess the capacity to define the different customer segments.

- Level 7.1.3 (Revenue stream), where we determine the capacity to distinguish how important the different customer segments are in relation to the whole value proposition of the enterprise.

- Level 7.2.1 (Customer relationship), where, once information about customer relationships is presented, we assess whether learners know how to find/select different customers and the best customers for their social enterprise and products.

- Level 7.2.2 (Channels to distribute products), where we check knowledge about how products reach customers, how difficult this process is and how many resources are needed.

- Level 7.3.1 (Key activities), where the capacity to describe the whole production process of the social enterprise in terms of activities to be performed is evaluated.

- Level 7.3.2 (Key resources), where we check whether learners have acquired knowledge about all the resources necessary to be able to realise the productive process.

- Level 7.3.3 (Key partners), where the goal is the knowledge acquired about the partners that the group would need to develop its business and social goals.

- Level 7.4 (Costs), where we evaluate if learners are able to recognize costs and their features (fixed, variables, initial capital).

- Level 8 (business plan), which has the aim of checking teamwork, social competencies and planning competencies.

- Final scene, when, having played the whole game and acquired the necessary knowledge, skills and attitudes, learners have to present their finalised business plan.

\section{Type of Quizzes}

In line with the overall objective to promote motivation and foster engagement, quizzes include a variety of exercises: 
TABLE IV. GAMe LeVels AND Sub-Levels [50]

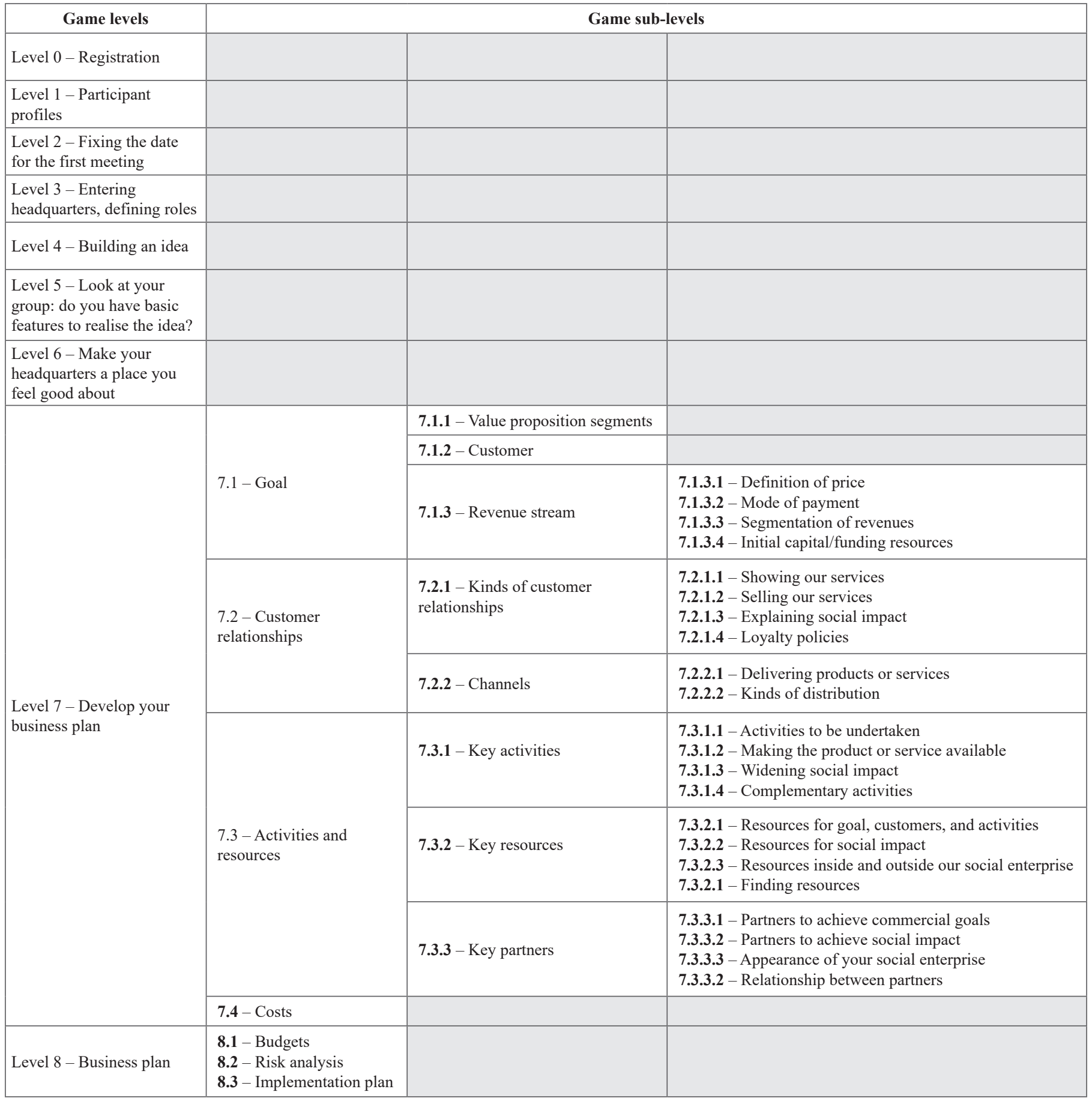

- Multiple choice: Given a question, definition, or term, choose the correct answer from the list offered.

- Matching concepts: Given a list of concepts and a list of definition or applications, match each element in the first list to the correct one in the second list.

- Given a set of features, provide a specific subset that fits with a given concept.

- Complete the sentence to compose definitions or describe how to run a task in practice in relation to items/stories presented as training material.

- Build the sentence: Given a set of words, build a sentence with them according to the request.
- Order concepts or features according to a set of defined criteria.

- Puzzles: in order to motivate effort from learners, fragmented images are linked to concepts and definitions. If concepts and definitions are linked correctly, an image appears.

- Divide the set of answers among group members: As a strategy of shared learning, every group member has to learn about concepts presented to contribute to the final common solution.

- True/false questions.

- Classification: Given a list of elements, choose the correct group in which they fit.

- Against the clock: Quizzes where the score obtained depends on how quickly the correct answer is provided. 
Learners are allowed to revisit their decisions and answers as a group: given the opportunity to check previous work, the group can refine its idea and its evolution, as well as realise the mistakes made, discover areas to be improved, etc. The possibility of going back in the work is intended to promote dialogue and knowledge-sharing among learners in the group, which is a beneficial way of learning collaboratively.

In addition, groups could also be provided with pre-defined solutions to the challenge that they are facing. Such solutions could come from pre-solved situations included in the game or from other groups' solutions. With this approach, we allow learners to see other ways to use concepts that they learn from training material, recognise good ideas to be included in their social enterprise and detect bad decisions that jeopardise the success of their entrepreneurial adventure.

\section{Skills Assessment}

Skills assessment happens by means of direct and indirect attitude feedback and by assigning scores to pre-determined positive behaviours.

In the case of implementation with feedback, the facilitator or another group will send comments; in the case of non-feedback implementation, only internal discussion is performed. For every activity in the BMC that coincides with a level in the platform, this assessment would consist of taking pieces of the work from other groups (anonymised) or pre-defined problem/solution sets and giving this group the opportunity to learn by (1) highlighting good decisions, ideas, resources, etc.; (2) incorporating elements into their own project; and/or (3) proposing improvements for the other group (this feedback could be sent to the other group or not, depending on the option selected). This assessment can be included in every learning outcome without repeating the same activity or level.

The gamification approach is used in the attitude evaluation, and it involves gaining points for the following positive behaviours:

- Accepting the role of leader: 50 individual points and 50 points for the group if the first candidate for being task leader accepts.
- Participating in the booking of the next meeting: 10 individual points +100 group points if everyone participates.

- Assisting with a meeting: 10 points +100 group points if everyone assists.

- Once a piece of internal material is read, 10 individual points for every participant who contributes in the chat +100 group points if everyone participates.

- The top contributor in the chat during the discussions in every scene obtains 10 extra points, and the group obtains 100 extra points if all team members participate in the discussion.

- For optional individual activities, 25 extra points will be given, + 50 extra group points if every group member performs the activity.

- For compulsory group activities, 10 individual points will be given to group members who participate in the activity, +50 group points if all group members participate.

- For optional group activities, 10 individual points will be given to every group member who participates in the activity, +100 group points if all group members participate.

Additionally, we have two possibilities for implementation: with or without feedback.

\section{Assessing Learning Outcomes}

In the following, we describe the assessment included in the proposal for knowledge, skills and attitudes related to every learning outcome.

For learning outcome (LO) 1, understanding the concept of social economy, we include the following assessment activities, which will be presented at the proper level throughout the game, according to the content taught at each moment. This first set of activities is related to knowledge (Table V).

To assess skills, we proposed the next optional individual activity: Given the work of another group (anonymous) or pre-defined problems and solutions, ask for one of the following, maybe repeated at several

TABLE V. LeARning Outcome 1 Assessment

\begin{tabular}{|c|c|c|c|}
\hline \multicolumn{4}{|c|}{ LO1 - Understanding the concept of social economy } \\
\hline \multicolumn{2}{|c|}{ Compulsory } & \multicolumn{2}{|c|}{ Optional } \\
\hline Individual & Group & Individual & Group \\
\hline $\begin{array}{l}\text { - Multiple - answer questions to select } \\
\text { the features of SEE. } \\
\text { - Select a number of values applicable } \\
\text { to the particular sector in which the } \\
\text { enterprise is allocated. } \\
\text { - Select the payment method chosen for } \\
\text { their idea. } \\
\text { - One question to select features of every } \\
\text { customer segment. }\end{array}$ & $\begin{array}{l}\text { - One question to match every possible } \\
\text { form of governance with its main } \\
\text { features. The group has to discuss and } \\
\text { to send a common answer. The test will } \\
\text { be passed when every governance form } \\
\text { is correctly assigned to its definition } \\
\text { and features. If more than three tries } \\
\text { are incorrect, group members will have } \\
\text { to review additional documentation to } \\
\text { better understand the concepts. } \\
\text { - From a list, select the two values that } \\
\text { make their enterprise different (related } \\
\text { to the idea, sector, etc.). This question } \\
\text { would need to extract responses from } \\
\text { previous work. } \\
\text { - Present two questions like this: For a } \\
\text { SEE in the X sector key resources for } \\
\text { commercial aims could be: (select two } \\
\text { from a list of five). } \\
\text { "Complete the sentences" activity } \\
\text { to link resources to every customer } \\
\text { segment. } \\
\text { - Link five resources to specific social } \\
\text { needs. More than one link could be } \\
\text { possible. }\end{array}$ & $\begin{array}{l}\text { - Present the ideas of enterprises } \\
\text { from different sectors to } \\
\text { decide if they are SEE or not. } \\
\text { This is an alternative to the } \\
\text { first compulsory individual } \\
\text { assessment. Asking for help from } \\
\text { other group members could be } \\
\text { allowed. A second round for } \\
\text { wrong answers is allowed. } \\
\text { - Gamification points: } 10 \text { points } \\
\text { for revisiting or modifying the } \\
\text { idea (needs facilitator validation). } \\
\text { - Select three local needs that will } \\
\text { be met by the SEE. This question } \\
\text { needs a pre-established list of } \\
\text { needs in every local context, } \\
\text { from which the learner can select } \\
\text { the most important ones. }\end{array}$ & $\begin{array}{l}\text { - Discussing wrong answers from } \\
\text { everyone and giving a common } \\
\text { answer. If } 60 \% \text { is obtained, } \\
\text { the test is individually passed. } \\
\text { Learners not passing in the } \\
\text { first-round pass with the obtained } \\
\text { score. }\end{array}$ \\
\hline
\end{tabular}


points: (1) choosing the best points; (2) presenting improvements; and (3) checking whether lessons learned during the process were incorporated in the proposal.

As previously explained, we include the assessment for the second learning outcome (LO 2, conception of the idea by a set of persons) in the knowledge category (Table VI).

The following activities are used to assess learning outcome 3 (establishing a business plan), in the knowledge category (Table VII).

In learning outcome 4, in which competences related to management, including communication and marketing, are taught, the design of the assessment for knowledge is as shown in Table VIII.

In this package, there is an initial skills self-evaluation, which is compulsory. Here, different aspects will be analysed, such as respecting opinions, participating in debates or discussions, confidence, detecting and solving errors, sharing responsibilities, technological skills, game usage and e-learning. Next, given the set of roles arisen from the test of group members, the learner has to match each of these roles with activities that fit with them.

In addition, an optional task can be performed in order to check roles in the SEE that will be developed. Thus, from the roles selected in the compulsory knowledge assessment group activity, the learner would have to select the one that best fits each of the group members.
The next learning outcome, number 5 , is about the creation of a conductive stakeholder environment. The assessment of knowledge related to this outcome is designed as shown in Table IX.

For skills, we here propose some optional individual activities:

- Given a set of characters, classify them into the correct segment of a given set.

- Given a set of products to be delivered to specific customers (considering segments) in specific locations, decide the best way to deliver them.

The sixth learning outcome is the one about evaluation and impact assessment, in which the SEE revises results obtained and impact achieved and checks if new investors need to be attracted. We have included the assessment activities for this LO in Table X.

The last learning outcome is related to operations. For this LO, we propose the set of assessment activities about knowledge included in Table XI.

For skills evaluation, we propose an optional group activity: The group is given a budget for some issue, but a problem arises and some money is needed to solve it. The group has to decide how to face this problem and where to find the needed money in its budget.

TABLE VI. LeARNing OUtcome 2 Assessment

\begin{tabular}{|c|c|c|c|}
\hline \multicolumn{4}{|c|}{ LO2 - Conception of the idea by a set of persons } \\
\hline \multicolumn{2}{|c|}{ Compulsory } & \multicolumn{2}{|l|}{ Optional } \\
\hline Individual & Group & Individual & Group \\
\hline
\end{tabular}

TABLE VII. Learning Outcome 3 Assessment

\begin{tabular}{|c|c|c|c|}
\hline \multicolumn{4}{|l|}{ LO3 - Establishing a business plan } \\
\hline \multicolumn{2}{|l|}{ Compulsory } & \multicolumn{2}{|l|}{ Optional } \\
\hline Individual & Group & Individual & Group \\
\hline
\end{tabular}


TABLE VIII. LEARNING OUtCome 4 AsSESSMENT

\begin{tabular}{|c|c|c|c|}
\hline \multicolumn{4}{|l|}{ LO4 - management } \\
\hline \multicolumn{2}{|l|}{ Compulsory } & \multicolumn{2}{|l|}{ Optional } \\
\hline Individual & Group & Individual & Group \\
\hline
\end{tabular}

TABLE IX. LeARning Outcome 5 Assessment

\begin{tabular}{|c|c|c|c|}
\hline \multicolumn{4}{|c|}{ LO5 - Creating a conductive stakeholder environment } \\
\hline \multicolumn{2}{|l|}{ Compulsory } & \multicolumn{2}{|l|}{ Optional } \\
\hline Individual & Group & Individual & Group \\
\hline
\end{tabular}

TABLE X. LeArning Outcome 6 Assessment

\begin{tabular}{|l|l|l|l|}
\hline \multicolumn{2}{|l|}{ O6 - Evaluation and impact assessment } & Optional \\
\hline Compulsory & Group & Individual & Group \\
\hline Individual & $\begin{array}{l}\text { A set of n questions has to be answered, } \\
\text { but each one will be presented to a } \\
\text { group member. That way, all of them } \\
\text { need to know about budget. }\end{array}$ & $\begin{array}{l}\text { A set of true/false questions } \\
\text { in which several rules about } \\
\text { implementation are presented. }\end{array}$ & $\begin{array}{l}\text { (Assuming different risks apply } \\
\text { to different sectors or kinds of } \\
\text { enterprise) given an enterprise } \\
\text { (real or ideal), select the three most } \\
\text { important risks it assumes. }\end{array}$ \\
\hline
\end{tabular}

TABLE XI. LEARNING OUtCome 6 AsSESSMENT

\begin{tabular}{|l|l|l|l|}
\hline LO6 - Evaluation and impact assessment & \multicolumn{2}{l|}{ Optional } \\
\hline Compulsory & Group & Individual & Group \\
\hline Individual & $\begin{array}{l}\text { From a list of activities, select the ones } \\
\text { related to social impact. } \\
\text { - The same template is used in different } \\
\text { points by presenting different sets of } \\
\text { activities every time (different correct } \\
\text { answers will be needed, of course). } \\
\bullet \begin{array}{l}\text { Given a list of elements, classify their } \\
\text { costs into fixed, variables, mandatory, } \\
\text { optional, remains, etc. }\end{array}\end{array}$ & $\begin{array}{l}\text { If.2.1's first question, the question } \\
\text { could be presented again here in } \\
\text { order to improve scoring and to fix } \\
\text { concepts. }\end{array}$ & $\begin{array}{l}\text { (Assuming different risks apply } \\
\text { to different sectors or kinds of } \\
\text { (real or ideal), select the three most } \\
\text { important risks it assumes. }\end{array}$ \\
\hline
\end{tabular}

\section{Case Study}

This pedagogical approach has been assessed with the support of five of the facilitators who took part in the piloting. They have been provided with the pedagogical description, and they have tested the platform, Social PlaNet, in which this pedagogical approach has been implemented. In this section, we outline their opinions [55]. The goal of this assessment was testing the effectiveness of the proposal as well as finding elements to be improved. 


\section{A. Pilot Information}

Five facilitators have participated in this assessment: three from Spain and two from Italy. Their assessment refers to the piloting activities carried out with 63 learners in total (36 in Spain and 27 in Italy), divided into 14 groups (seven in each country). Out of these 14 groups, two were run testing a completely online training/gaming model, whereas the others were run with a blended model. Learner demographics were quite varied, ranging from a group of African refugees in one of the Italian pilots to unemployed but qualified people in some of the Spanish pilots. Pilots were run from May till June 2017, with the work of each group lasting two to three weeks on average. There were two to three meetings per week, with each lasting two-anda-half to three hours.

\section{B. Results}

Facilitators were asked about the benefits for learners that they found in taking part in the pilots, with specific reference to the learning experience and outcomes.

A first general finding was that the pedagogical approach was effective in relation to the expected learning outcomes, since it enhanced the development of the expected knowledge and skills in the terms defined in Table III. The group composition of the pilots had a great influence on the type of most-enhanced skills, since facilitators emphasised different skills in each of them. That way, groups of lowskilled and low-literacy learners were encouraged to develop soft skills (self-esteem, empowerment, capacity to work in groups) rather than specific knowledge and competences. This was the case, for instance, with the Italian pilot addressing African refugees, where the facilitator stated that 'the biggest learning outcome - considering the specificity of the target group (African refugees) was a cultural one: the hardest part was to convince them they could become entrepreneurs (and not just execute the orders of someone else), adding value to the community rather than thinking only of profit for personal benefit (as social entrepreneurs)'. However, in groups involving already-experienced social entrepreneurs and unemployed people with a higher education profile, the main learning outcomes achieved were the following, according to the facilitators interviewed:

- Improvement of skills and knowledge in relation to the creation and management of social economy enterprises, with specific reference to the use of the $\mathrm{BMC}$ and marketing techniques.

- Improvement of knowledge about social entrepreneurship.

- Improvement of social awareness.

- Improvement of tolerance for frustration.

- Improvement of collaborative skills and teamwork (working together on a common project).

As anticipated in section V.A, two out of the 14 groups analysed in this paper tested the game completely online, in line with the initial idea of the project to deliver an online game on social entrepreneurship. The results of the online testing were disappointing, since the technical challenges met by learners in proceeding with the game ended up in killing motivation to play, and the two online groups did not complete the testing phase. On the other hand, the remaining 12 groups, which adopted an in-person approach (all learners connected to a PC, but in the same room and with the in-person support of the facilitator), successfully completed the testing, developing business ideas and related business plans.

Once the training program was finalized, about $60 \%$ of participants were intended to became entrepreneurs in the real life [55].

\section{Discussion}

Based on the above results, we can conclude that the pedagogical model elaborated as a support for the Social PlaNet game was partly successful, since it worked with a stronger than foreseen role of the facilitators in guiding the groups and as long as the testing was run in person, or with a blended approach. Technical difficulties related to the gameplay concern both the game development (with specific feedback provided by facilitators on the changes needed to make the game more user-friendly) and the IT skills of the targeted participants. Based on the pilot results, the team is now working to improve the game, making it more user-friendly and granting more power to facilitators to intervene on the online game platform with ad-hoc support material for the training. The recommendations that will be produced for future facilitators willing to use the game will also refer to the need for an introductory session on basic IT skills to allow for more fluent and relaxed gameplay.

\section{CONCLUSIONS AND FURTHER WORKS}

In this paper, we have presented the pedagogical approach developed in the Social Seducement European project, which has been included in the platform Social PlaNet. This pedagogical approach is based on three main principles: the use of the instructional design model ADDIE; the European Qualification Framework (EQF); and the particularities of the social economy. Based on these foundations, we have presented the set of learning outcomes that are taught in the platform, obtained from a deep study of the literature as well as a wide set of interviews with main actors in this field.

The pedagogical model works on a set of knowledge, skills, and attitudes learned through a gamified e-learning tool (Social PlaNet). This game encourages learners to become social entrepreneurs that develop a business plan for their own social economy enterprises. To support this learning process, Social PlaNet includes a set of levels that help learners to advance from the initial idea to the final business plan by using real-life stories as means to inspire them. Additionally, the game includes learning materials, distributed by country, in order to provide native resources for every learner in every language. This specific feature focused on language-based resources provides the learner with a local library of resources, along with the international scope of the game. Finally, this process is made more dynamic by the inclusion of gamification points, which learners use to furnish their offices, so that the space accommodates their social entrepreneurial activities. This contextualisation of the personal office facilitates a deeper identification of the learner with the role of entrepreneur.

This pedagogical approach has been tested in two pilots developed in Italy and Spain by means of the Social PlaNet platform. These pilots show that results differ depending on the learners' features: the lower the level of literacy, the higher the impact in terms of soft skills; the higher the level of literacy, the higher the level of specific skills, knowledge and attitudes acquired. Further, this game can address various learner profiles that will get particular benefits based on their features. This multi-faceted use of the game allows for multiple learner targets and competences to be addressed using the pedagogical model by Social PlaNet.

Future work will combine a) additional pilots, in order to widen the scope of these results; b) additional facilitators that will support the development of Social PlaNet; and c) a facilitators' network that is fostered by the project partners group, with the aim of giving support to incoming facilitators that start the training of new learner groups.

Social PlaNet is available to be used at the following URL: http:// ss.epscms.com. It is open to be used by anyone who wants to use this learning platform for social entrepreneurship training. The website and guidelines are available in several languages, and can be downloaded at https://www.socialseducement.net/game-and-resources . 
APPENDICES

\section{A. Appendix I}

Story title: 'Co-op57: From company to worker's cooperative' Context

Co-op57 is a financial services cooperative that was created in 1995 as a consequence of long years of workers' struggle: When the publisher Bruguera went bankrupt, some of the fired employees put part of their compensation into a common fund to promote social economy projects. They chose the cooperative model because of their commitment to social change.

\section{Problem}

Many times, banks ask for very high guarantees before granting a loan, but loan-seekers have difficulty meeting these requirements. Some fired workers have business ideas and need initial support to fund their projects.

The financial crisis made this problem still bigger because public funding comes late or never. In this situation, many enterprises have difficulty providing their services and products.

\section{Solution}

Due to the circumstances in which it arose, Co-op57 is highly engaged to change the economy's rules. Therefore, it offers financial services (loans) for auto-managed projects for social change and workers' fight to contribute to change the economy's rules and help create new ways of work.

The most important thing in Co-op57 is confidence. Thus, every client in the co-op becomes a partner, having the power to give opinions and participate in the decision-making process. This makes every client feel like an owner.

Transparency is very important for confidence. Social impact is measured by seeing how projects advance and new partners arrive, but there is no index by which to measure it. Co-op57 has a newsletter every six months provide information about new partners and projects to which it has given loans, along with the amounts of those loans. At present, it has 700 entities as partners, which it considers as having a high degree of social impact.

Projects are evaluated according to their social repercussions and whether they contribute to new types of economy and employment. Evaluating the risks of proposals that the co-op receives is necessary so it can be responsible with partners. However, metrics are different because the viability of the project is very important. Co-op57 usually contributes to the improvement of proposals in order to make the initial projects viable and, hence, able to access loans.

Locally, the co-op promotes new social and caring projects, although it also works with national foundations and organizations focused on changing the economy (Alternative Economy Network, Cooperatives Federation) as well as building a person-based economy.

Its governance structure is based on consensus by a horizontal organization and on territorial semi-autonomous management. Decisions are sent to a central board, which makes the process slow but democratic. However, this auto-management and need for coordination is highly challenging.

Benefits obtained from loans are partially saved. The rest of the benefits are invested annually as partners decide. So far, they have always decided to retain them in Co-op57 to face possible unexpected events.

\section{B. Appendix II}

\begin{tabular}{|c|c|}
\hline \multicolumn{2}{|c|}{ LO 1 - Understanding the concept of social economy } \\
\hline General description of social economy & $\begin{array}{l}\text { - https://es.wikipedia.org/wiki/Econom\%C3\%ADa_social_en_España } \\
\text { - http://www.cepes.es/social/econ_social_que_es }\end{array}$ \\
\hline Typology of social economy enterprises & $\begin{array}{l}\text { - Cooperatives: http://www.cepes.es/social/entidades_cooperativas } \\
\text { - Labor society: http://www.cepes.es/social/entidades_sociedades_laborables } \\
\text { - Mutuals: http://www.cepes.es/social/entidades_mutualidades } \\
\text { - Insertion companies: http://www.cepes.es/social/entidades_empresas_insercion } \\
\text { - Fishermen's associations: http://www.cepes.es/social/entidades_cofradias_pescadores } \\
\text { - Special Employment Centres: http://www.cepes.es/social/entidades_centros_empleo }\end{array}$ \\
\hline \multicolumn{2}{|c|}{ LO 2 - Conception of the idea by a set of persons } \\
\hline $\begin{array}{l}\text { Guide for entrepreneurs on the constitution } \\
\text { of social economy enterprises }\end{array}$ & - http://www.cepes.es/index.php?action=carga\&a=archivo_6f6cc27_22-10-13_pdf.pdf \\
\hline How to create a cooperative & $\begin{array}{l}\text { - http://www.cepes.es/index.php?action=carga\&a=archivo_5f6cc27_22-10-13_pdf.pdf } \\
\text { - http://www.cepes.es/index.php?action=carga\&a=archivo_2f6cc27_22-10-13_pdf.pdf }\end{array}$ \\
\hline Business Model Canvas & - http://www.emprendedores.es/gestion/modelo-3 \\
\hline \multicolumn{2}{|c|}{ LO 4 - Management, including communication and marketing } \\
\hline Concept and importance & $\begin{array}{l}\text { - http://www.cepes.es/index.php?action=carga\&a=archivo_2f6cc27_22-10-13_pdf.pdf } \\
\text { - https://dialnet.unirioja.es/descarga/articulo/2649005.pdf }\end{array}$ \\
\hline \multicolumn{2}{|c|}{ LO 5 - Creation of conductive stakeholders' environment } \\
\hline Concept and importance & • http://www.anel.es/la-creacion-de-redes-principal-reto-para-el-desarrollo-de-la-economia-social/ \\
\hline \multicolumn{2}{|l|}{ LO 6 - Evaluation and impact assessment } \\
\hline Concept and importance & - http://www.economiasolidaria.org/documentos/medicion_del_valor_social_y_el_impacto \\
\hline \multicolumn{2}{|l|}{ LO 7 - Operations } \\
\hline
\end{tabular}




\section{ACKNOWLEDGMENT}

This work is partially supported by the project Social Seducement (contract number: 2014-1-UK01-KA200-001830) funded by the European Commission under the Erasmus + Programme, and the Research Institute for Innovation \& Technology in Education (UNIR iTED) (http://ited.unir.net) at Universidad Internacional de La Rioja (UNIR).

\section{REFERENCES}

[1] Waitz, T. (1863). Introduction to anthropology (Vol. 1). Anthropological Society.

[2] Cohen, R. (1978). Ethnicity: Problem and focus in anthropology. Annual review of anthropology, 379-403.

[3] Aarseth, E. (2001). Computer game studies, year one. Game studies, 1(1), $1-15$.

[4] Bernard, H. R. (2011). Research methods in anthropology: Qualitative and quantitative approaches. Rowman Altamira.

[5] Hindle, K. (2002). A grounded theory for teaching entrepreneurship using simulation games. Simulation \& Gaming, 33(2), 236-241.

[6] Schwartzman, H. (Ed.). (2012). Transformations: The anthropology of children's play. Springer Science \& Business Media.

[7] Prensky, M. (2005). Computer games and learning: Digital game-based learning. Handbook of computer game studies, 18, 97-122.

[8] Prensky, M. (2009). H. sapiens digital: From digital immigrants and digital natives to digital wisdom. Innovate: journal of online education, 5(3), 1.

[9] Steyaert, C., and Hjorth, D. (Eds.). (2008). Entrepreneurship as social change: A third new movements in entrepreneurship book (Vol. 3). Edward Elgar Publishing.

[10] Mishra, P., and Shrawankar, U. (2016) Comparison between Famous Game Engines and Eminent Games. International Journal of Interactive Multimedia and Artificial Intelligence 4(1), 69-77.

[11] Trouillot, M. R. (2016). Global transformations: Anthropology and the modern world. Springer.

[12] Scupin, R. (2015). Cultural anthropology a global perspective. Pearson.

[13] Horst, H. A., \& Miller, D. (Eds.). (2013). Digital anthropology. A\&C Black.

[14] Malinowski, B. (1929). Practical anthropology. Africa, 2(01), 22-38.

[15] Fried, M. H. (1975). The notion of tribe. Benjamin-Cummings Publishing Company.

[16] Keesing, R. M. (1981). Cultural anthropology: A contemporary perspective. Holt McDougal.

[17] Pfaffenberger, B. (1992). Social anthropology of technology. Annual review of Anthropology, 491-516.

[18] Guimaraes, M. J. (2005). Doing anthropology in cyberspace: Fieldwork boundaries and social environments. Virtual methods: Issues in social research on the Internet, 141-56.

[19] Piaget, J. (1962). Play, dreams, and imitation in childhood. New York: Norton Books.

[20] Gross, R. (2010). Psychology: the science of mind and behavior. Hodder Education: London.

[21] Gee, J. P. (2003). What video games have to teach us about learning and literacy. Computers in Entertainment (CIE), 1(1), 20.

[22] Malaby, T. M. (2007). Beyond play a new approach to games. Games and culture, 2(2), 95-113.

[23] Malaby, T. M. (2009). Anthropology and play: The contours of playful experience. New Literary History, 40(1), 205-218.

[24] Kline, S., Dyer-Witheford, N., \& De Peuter, G. (2003). Digital play: The interaction of technology, culture, and marketing. McGill-Queen's PressMQUP.

[25] Raessens, J. (2006). Playful identities, or the ludification of culture. Games and Culture, 1(1), 52-57.

[26] S. Aceto, D. Burgos, D. Parente. (2015) Guide for developing the game and its environment. IO1 report, Social Seducement Project (2014-1-UK01KA200-001830)

[27] New Media Consortium (2013). NMC Horizon Report 2013 Higher Education Edition, retrieved from https://www.nmc.org/pdf/2013horizon-report-HE.pdf
[28] New Media Consortium (2015). NMC Horizon Report 2015 Higher Education Edition, retrieved from https://www.nmc.org/publication/nmchorizon-report-2015-higher-education-edition/

[29] New Media Consortium (2017). NMC Horizon Report 2017 Higher Education Edition, retrieved from http://cdn.nmc.org/media/2017-nmchorizon-report-he-EN.pdf

[30] BinSubaih, A., Maddock, S., \& Romano, D. (2009). Serious games for the police: Opportunities and challenges. Special Reports \& Studies Series at the Research \& Studies Center (Dubai Police Academy).

[31] McClarty, K. L., Orr, A., Frey, P. M., Dolan, R. P., Vassileva, V., \& McVay, A. (2012). A literature review of gaming in education. Gaming in education, $1-35$.

[32] Ulicsak, M. (2010). Games in education: serious games. Bristol: Futurelab.

[33] Chin, J., Dukes, R., Gamson, W. (2009). Assessment in Simulation and Gaming: A review of the last 40 years. Simulation and Gaming 40(4), 553568

[34] Malone, T (1980). What Makes Things Fun to Learn? A Study of Intrinsically Motivating Computer Games. Palo Alto: Xerox

[35] Kirriemuir, J., McFarlane, A. (n.d.) Literature Review in Games and Learning. FutureLab Series, report 8

[36] Stewart, J., Bleumers, L., Van Looy, J., Mariën, I., All, A., Schurmans, D., Willaert, K., De Grove, F., Jacobs, A., and Misuraca, G. (2013). The Potential of Digital Games for Empowerment and Social Inclusion of Groups at Risk of Social and Economic Exclusion: Evidence and Opportunity for Policy. Joint Research Center, Institute for Prospective Technological Studies (JRC-IPTS).

[37] Stuart, A. (2014). A blended learning approach to safety training: Student experiences of safe work practices and safety culture. Safety Science 62, 409-417.

[38] Antonaci, A., Dagnino, F. M., Ott, M., Belloti, F., Berta, R., De Gloria, A., Lavagnino, E., Romero, M., Usart, M., and Mayer, I. (2015). A gamified collaborative course in entrepreneurship: focus on objectives and tools. Computers in Human Behaviours 52, 1276-1283.

[39] Jensen, R. 50 great sites for serious educational games, available online at: http://www.onlinecolleges.net/50-great-sites-for-serious-educationalgames/

[40] Kuratko, D. F. (2016). Entrepreneurship: Theory, process, and practice. Cengage Learning.

[41] O'Rourke, M. (2014). Increasing engagement with vocational education and training: a case study of computer games-based safety training. 2013 postgraduate research papers: a compendium. Adelaide, Australia: National Centre for vocational education research, 113-133.

[42] Belloti, F., Berta, R., de Gloria, A., Lavagnino, E., Antonaci, A., Dagnino, F., Ott, M., Romero, M., Usart, M., and Mayer. I. S. (2014). Serious games and the development of an entrepreneurial mindset in higher education engineering students. Entertainment Computing, 357-366.

[43] Lim, T., Loucher, S., Hauge, J. B., Stanesco, I. A., Ortiz, I. M., MorenoGer, P., Belloti, F., Carvalho, M. B., Earp, J., Ott, M., Arnab, S., and Berta, R. (2014). Narrative Serious Game Mechanics (NSGM) - Insights into the Narrative-Pedagogical Mechanism. LNCS 8395, 23-34.

[44] Lukosch, H., van Bussel, R., and Meijer, S. A. (2013). A serious game design combining simulation and sandbox approaches. LNCS 8264, $52-$ 59.

[45] Mollick, E. (2014). Entrepreneur simulation: the startup game. Harvard Business Publishing for educators.

[46] Stuart, A. (2014). A blended learning approach to safety training: Student experiences of safe work practices and safety culture. Safety Science 62, 409-417.

[47] Nichols, E., and Wright, A. L. (2015) Using the Everest Team Simulation to Teach Threshold Concepts. Journal of Management Education 39(4), 531-537.

[48] Almeida, F. L. F. (2017). Learning entrepreneurship with serious games a classroom approach. Information Technology 2(1), 1-4.

[49] EUROSTAT. v3.4.1-20170407-5840-PROD_EUROBASEDATAEXPLORER PRODmanaged12. Retrieved from http://appsso.eurostat. ec.europa.eu/nui/show.do?dataset=lfsi_sup_a\&lang=en on 2018, Jan 23th.

[50] S. Aceto, D. Burgos, S. Francario, R. Goergen K. Junge, N. Padilla, D. Parente. (2016) Guide on the Social Seducement RPG learning model. IO3 report, Social Seducement Project (2014-1-UK01-KA200-001830)

[51] N. Padilla-Zea, S. Aceto and D. Burgos, "Social Seducement: Towards the 
foundations of a pedagogical model". Ingeniería Solidaria, vol. 13(21), January 2017.

[52] Branch, R. (2009). Instructional Design: The ADDIE approach. Springer: New York.

[53] EQF, European Commission, https://ec.europa.eu/ploteus/content/ descriptors-page. Last access on March, 8th

[54] K. Junge, C. Castellanos, S. Francario, E. Klaer, R. Goergen and J. Keim. (2015) Target needs' analisys report. IO2 report. Social Seducement project (2014-1-UK01-KA200-001830).

[55] Cullen, J., Drabble, D. (2017). Social Seducement. RPG model validation report. IO6 report. Social Seducement project (2014-1-UK01KA200-001830).

[56] González-González, C.S., del Río, N.G., Navarro-Adelantado, V. (2018) Exploring the Benefits of Using Gamification and Videogames for Physical Exercise: a Review of State of Art. International Journal of Interactive Multimedia and Artificial Intelligence, 5(2):46-52.

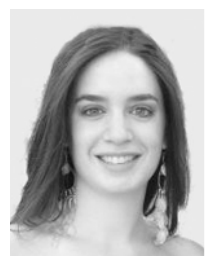

Natalia Padilla-Zea

Dra. Natalia Padilla-Zea is Assisstant Professor at the Universidad Internacional de La Rioja (UNIR). She received her PhD from the University of Granada. She is researcher at the Research Institute for Innovation \& Technology in Education (UNIR iTED, http://ited.unir.net), as part of Vicechancellor for Knowledge Transfer and Technology (http:// transfer.unir.net). Her main line of research is focused on e-learning, gamification and game-based learning. She develops her teaching activity at the Engineering and Technology School of UNIR.

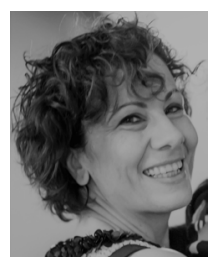

Stefania Aceto

Stefania Aceto, born in Bologna (Italy) on 21.12.1970, graduated in Political Sciences and Economics. Since 1998 she is active in research and policy advisory activities concerning innovation in learning; technology enhanced learning and internationalisation of Higher Education. From 2001 to 2013 she was Head of the Observatory Unit on Learning Technologies at Scienter, Italy, conducting research on policy, market and innovative practices in the field of e-learning across all sectors of Education and Training. From 2013 to 2014 she collaborated with the Menon Network EEIG coordinating FP7 and Lifelong learning projects in the area of learning, technology, creativity and innovation. Since 2015 she is a senior researcher and Project manager at the Universidad Internacional de La Rioja (UNIR), working on projects related to quality assurance, game-based learning, social inclusion, digital competences and Open Education.

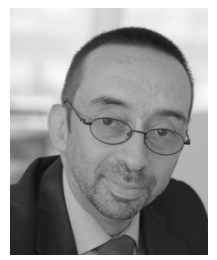

Daniel Burgos

Prof. Dr. Daniel Burgos works as Vice-rector for Knowledge Transfer \& Technology (http://transfer.unir.net), UNESCO Chair on eLearning and ICDE Chair in OER (http:// research.unir.net/unesco) at Universidad Internacional de La Rioja (UNIR, http://www.unir.net). He is also Director of the Research Institute for Innovation \& Technology in Education (UNIR iTED, http://ited.unir.net). He contributes to research and implementation projects about, i.e. social entrepreneurship (Social Seducement), regional Open Education (OpenMed), clustered Open Education (Open Educators Factory), eLearning (Intuitel), STEM (Inspiring Science Education), etc., funded by the European Commission and Worldwide. His interests are mainly focused on Educational Technology and Innovation: Adaptive/ Personalised and Informal eLearning, Open Education, Learning Analytics, Social Networks, eGames, and eLearning Specifications. He has published over 100 scientific papers and 15 books on these matters. He has been the jury chair of the 2016 and 2018 UNESCO Prize for the Use of ICTs in Education. He holds degrees in Communication (PhD), Computer Science (Dr. Ing), Education (PhD), Anthropology $(\mathrm{PhD})$ and Business Administration (DBA). 